\title{
Income Maintenance for the Soviet Aged
}

\author{
JOSEPH L. PORKET*
}

\section{ABSTRACT}

Hitherto, Western analysts of Soviet affairs have largely neglected Soviet persons beyond retirement age. These persons constitute a heterogeneous and expanding social category, and their lot has a number of dimensions. The present examination concentrates on their economic status and participation in social production, regarding both as an outcome of the Soviet régime's changing policies. It indicates a modest level of success in retaining the working involvement of retired people during the early post-retirement years. At the same time it uncovers many issues and situations which are familiar to gerontologists in Western countries.

\section{Introduction}

The Soviet régime has always advertised its care for the aged and depicted it as a true manifestation of socialist humanism. Yet, with the exception of general statements, legal provisions and scattered quantitative data, there is a marked scarcity of reliable information on what kind of life the aged as a social category actually lead.

Since approximately the early seventies, it is true, the official culture and especially local scholars have paid somewhat greater attention to the aged than before. But the underlying reason has been practical rather than humanitarian, namely to encourage able-bodied individuals either to carry on working after their retirement or to postpone their retirement.

Not surprisingly, the present examination cannot deal with all dimensions of the lot of the Soviet aged who, as a social category, consist of persons of retirement age, irrespective of whether they do or do not

- Dr Porket is an independent scholar. He can be contacted at 26 Crescent Gardens, Eastcote, Ruislip, Middlesex $\mathrm{HA}_{4}$ 8TA, England. 
receive an old-age pension under a compulsory state old-age pension scheme. Instead, it will confine itself to the question of their economic status or relative economic position, and to that of their participation in social production.

\section{Coverage}

In Tsarist Russia, where in I 9 I 3 close to four-fifths of the population were dependent on agriculture, old-age pension programmes existed only for government employees. In 19 I 2 , Lenin formulated the principles on which a comprehensive social security system should be based: inter alia, it should cover all wage earners and their families, and provide assistance in all cases of incapacity, including old age. In contrast, a bill drafted by the Bolsheviks in 1914 stipulated a nearly universal coverage, but omitted old-age pensions.

Between the October Revolution and I928, the Soviet régime passed a number of decrees and laws relating to social security. ${ }^{1}$ However, with the exception of a decree of 31 October 1918 which remained a dead letter, these decrees and laws applied exclusively to those who sold their labour, thus excluding the self-employed, and did not recognize old-age pensions. Old age was viewed as a kind of invalidity.

A separate old-age pension scheme was introduced only in 1928 . While by that time life expectancy at birth was 44 years, ${ }^{2}$ the retirement age was set at 60 for men and 55 for women. To be eligible for an old-age pension, which was related to previous earnings, an employment record of 25 years was further needed. On the other hand, there was no longer a disability requirement.

Initially, the scheme was restricted to blue-collar workers in the textile industry. Later, though, it was gradually extended, until by $193^{2}$ it covered practically all blue-collar workers and as from I January I $93^{8}$ all white-collar workers as well. Nevertheless, in i 94 I out of $3,967,000$ pensioners merely 242,000 were old-age pensioners. ${ }^{3}$ Yet in 1939 persons of retirement age amounted to 17 million or 8.9 per cent of the total population. ${ }^{4}$

On I October 1956, a new state pensions law came into force. ${ }^{5}$ Adopted after the Twentieth Congress of the CPSU, it completely revised the existing system of old-age, invalidity and survivors' pensions. ${ }^{6}$ Inter alia, it increased substantially the level of benefits, thus vastly improving the economic situation of pensioners, and broadened the coverage. ${ }^{\text {? }}$

Though the $195^{6}$ Act broadened the coverage, it did not apply to 
collective farmers who, with their dependants, constituted about onethird of the population. ${ }^{8}$ They continued to be covered not by a state pension scheme, but by a separate system based on mutual aid and having the character of an assistance programme. Mutual aid societies for peasants were established in $19^{2} \mathrm{I}$ and, ten years later, transformed into mutual aid societies for collective farmers.

Not surprisingly, the system had serious shortcomings. It was neither universal, nor uniform, nor stable, nor devoid of discrimination. Some collective farms lacked mutual aid funds. Where set up, the magnitude of pensions varied from one collective farm to another and, moreover, could be raised or reduced every year. And an individual could be denied a pension if his family was able to support him, if he displayed an improper attitude towards work or collective property, and the like.

In 1964, the total number of pensioners in the country amounted to nearly 26 million. Of these, less than 2.6 million were receiving pensions from collective farms, ${ }^{9}$ but this low figure did not include the few collective farmers who were receiving a state pension. ${ }^{10}$

As from I January i 965 , at last, a state pension scheme for collective farmers was established. ${ }^{11}$ Under it, collective farmers were entitled to old-age and invalidity pensions, and their family dependants to survivors' pensions. By the beginning of the next year, 7.9 million collective farmers were receiving pensions, 7 million of them an old-age one, and the total number of pensioners in the country reached 32 million. ${ }^{12}$

The scheme, the officially given reason for which was to enhance the interest of collective farmers in raising agricultural production, was kept separate from that for workers and was also less generous. Subsequently, though, it was largely equalised with that for workers. For example, from I January 1968 collective farmers were able to retire at the same age as workers, ${ }^{13}$ and from I July 197 I the method of calculating old-age, invalidity and survivors' pensions for workers was extended to collective farmers.

While in 197 I the two schemes were equalised with respect to the method of calculating pensions as well as with respect to the maximum old-age, invalidity and survivors' pensions, ${ }^{14}$ they were not equalised with respect to the minimum old-age, invalidity and survivors' pensions. Besides, the pensions of collective farmers were to be reduced by 15 per cent if they lived permanently in rural localities and were members of a household with a private plot exceeding 0.15 hectare..$^{15} \mathrm{On}$ the other hand, collective farms were allowed to supplement the state pensions of collective farmers, as well as to grant personal pensions. ${ }^{16}$

From the point of view of income maintenance provided by the Soviet one-party state, then, it is possible and necessary to distinguish three 
subcategories of the Soviet aged. First, there are those aged who receive an old-age pension either under the compulsory state old-age pension scheme for workers or under that for collective farmers.

Secondly, there are those aged who receive another state pension, particularly a survivor's one, or a personal one, or a long-service one. The last two kinds of pension, upon which the present examination has hitherto omitted to remark, date from before the Second World War, but since their original introduction have undergone a number of changes. ${ }^{17}$

Finally, there are those aged who receive none of the state pensions mentioned above. Over the years, this subcategory has been diminishing: for instance, worker families had to provide for nine out of each ten elderly relatives in the thirties and the forties, for five to six in the late fifties, and for one to two in the early seventies. ${ }^{18}$ Nevertheless, it most probably has not disappeared completely. ${ }^{19}$

In the following, unless stated otherwise, only retired workers will be considered. As used here, the term 'workers' denotes employees of any kind, manual and non-manual alike, and the term 'wages' denotes both wages and salaries.

\section{Entitlement and Rates}

Since the adoption of the I 956 Act, upon retirement white-collar and blue-collar workers can be awarded either a full or a partial old-age pension. To be eligible for a full old-age pension, a male worker must be 60 years of age and have an employment record of 25 years, while a female worker must be 55 years of age and have an employment record of 20 years. Those workers who do not have the employment record required but have at least five years of service, three of them immediately prior to retirement, are eligible for a partial old-age pension.

However, some categories of workers are eligible for a full old-age pension at an earlier age, often with a reduced qualifying period as well. These include workers who work underground, in unhealthy conditions, at high temperatures, or in the Far North; female weavers and spinners at textile mills; women who have raised five or more children; blind workers; and so on. ${ }^{20}$

An old-age pension award is calculated from the reference wage. The basic rate depends on the level of the reference wage and the category of work. As follows from Table I, the basic rate is either an ordinary one or a privileged one, in both cases varying inversely with the level of the reference wage. Most workers are entitled to the ordinary rate. ${ }^{21}$

The basic rate is increased by to per cent for an uninterrupted period 
T A B LE I . Basic rates for old-age pension awards (as established by the 1956 $A c t)$

\begin{tabular}{ccc}
\hline & $\begin{array}{c}\text { Monthly basic old-age pension award as } \\
\text { a percentage of the reference wage }\end{array}$ \\
\cline { 2 - 3 } $\begin{array}{c}\text { Monthly reference } \\
\text { wage (roubles) }\end{array}$ & $\begin{array}{c}\text { Ordinary work } \\
\text { (ordinary old-age } \\
\text { pension rate) }\end{array}$ & $\begin{array}{c}\text { Underground, unhealthy } \\
\text { and dangerous work } \\
\text { (privileged old-age } \\
\text { pension rate) }\end{array}$ \\
\hline Up to 35 & 100 & 100 \\
$35.1-50$ & 85 & 90 \\
$50.1-60$ & 75 & 80 \\
6o.1-80 & 65 & 70 \\
80.1-100 & 55 & 60 \\
Over 100 & 50 & 55 \\
\hline
\end{tabular}

TA B LE 2. Minimum wage and old-age pension (roubles per month)

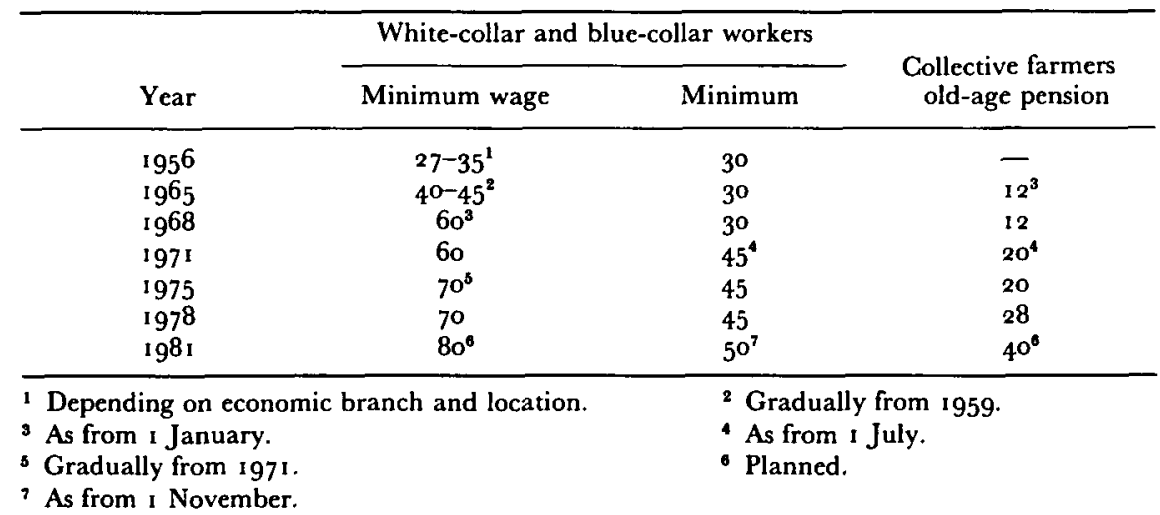

of service of at least fifteen years or for a total period of service exceeding the qualifying period by ten years. Besides, it is increased by another Io per cent for non-employed retired workers with a dependant unable to work, and by i 5 per cent for those with two or more dependants unable to work.

With a few exceptions, the maximum old-age pension award (including supplements) amounts to 120 roubles per month. ${ }^{22}$ While it has remained unchanged since 1956 , Table 2 shows that the minimum old-age pension award for workers has been raised twice, so that the ratio between them has declined from $4: \mathrm{I}$ in 1956 to $2.4: \mathrm{I}$ in $\mathrm{r} 98 \mathrm{I}$. A similar equalizing tendency has not existed between the minimum old-age pension award and the minimum wage, though.

For the purposes of calculating an old-age pension award, the 
reference wage is defined as actual average monthly earnings received in the last twelve months of employment or, at the worker's request, in any five consecutive years out of the last ten before retirement. The available evidence suggests that the large majority of workers choose the first alternative: $9^{2}$ per cent according to a sample survey of 1969 , and 98.1 per cent according to another of $1976 .{ }^{23}$

The prevalence of the first alternative stems from the workers' interest in being awarded as high an old-age pension as possible. As long as nominal wages rise, a recent reference wage is likely to be more advantageous than a less recent one. Besides, a period of twelve months gives workers a better opportunity to bloat their reference wage than a period of several years.

Soviet sources admit that the bloating of the reference wage often occurs through various irregularities in which both workers and the enterprise management are actively involved, ${ }^{24}$ without doubt with at least a tacit approval on the part of the trade union and Party functionaries. Consequently, the reference wage tends to be insufficiently linked to performance and to contain a social element, thus violating the officially proclaimed principle of 'to each according to his work'.

One of the motives underlying the workers' interest in being awarded as high an old-age pension as possible is their not unjustified assumption that in all probability their old-age pension awards will remain frozen throughout their retirement, ${ }^{25}$ because old-age pensions previously awarded are not automatically adjusted to the rising wage level.

Not surprisingly, the practice of manipulating the reference wage during the last twelve months of employment has been criticised. To do away with it, it was proposed in $198 \mathrm{I}$, the reference wage should be redefined as actual average monthly earnings received in the last twenty years of employment. And to cushion the financial impact of the change, the existing scale for calculating old-age pensions should be increased by 20 per cent. ${ }^{26}$

\section{Average Pension}

While legal provisions concerning income maintenance for the aged are widely publicised, Soviet statistical yearbooks offer neither the average old-age pension awarded in a particular year, nor the average old-age pension in payment (i.e. the average of all old-age pensions paid in a particular year, irrespective of when they were awarded), nor the structure of old-age pensions in payment. They merely enable one to compute the average pension in payment, covering all kinds of state 
TABLE 3. Average wage and pension

\begin{tabular}{llllll}
\hline & 1960 & 1965 & 1970 & 1975 & 1980 \\
\hline $\begin{array}{l}\text { A. Average monthly } \\
\text { wage in the } \\
\text { national economy }\end{array}$ & 80.6 & 96.5 & 122.0 & 145.8 & 168.9 \\
$\begin{array}{l}\text { (roubles) } \\
\begin{array}{l}\text { B. Average monthly } \\
\text { pension (roubles) }\end{array}\end{array}$ & 28.7 & 33.3 & 33.7 & 45.8 & 57.0 \\
$\begin{array}{l}\text { B as a percentage } \\
\text { of A (per cent) }\end{array}$ & 35.6 & 34.5 & 27.6 & 31.4 & 33.7 \\
\hline
\end{tabular}

Sources: J. L. Porket, Retired workers under Soviet-type socialism, Social Policy and Administration, 16, 3 (1982), 261, table 8; Narodnoe khozyaistvo SSSR (1980), pp. $3^{81}$ and 411 ; Vestnik statistiki, no. $10(1982)$, p. 66 .

pension (old-age, invalidity, survivors', etc.) and all categories of pensioners (workers, collective farmers, etc.)

Between I 960 and 1980 , it follows from Table 3 , the average pension payment doubled in absolute terms. Yet, although in 1980 the relative economic position of the average pensioner was more favourable than that in 1970 , it was below that in 1960 . For comparison, the average pension amounted to 36 per cent of the average wage in $1926-7$, to 21.5 per cent in 1940 , to 16.0 per cent in $195^{\circ}$, and to 22.3 per cent in $1955^{27}$

Despite official secretiveness, occasionally some data concerning the average old-age pension in payment do appear in Soviet scholarly publications. On the basis of these rare data Alastair McAuley estimates that the average monthly old-age pension of retired workers reached 45 roubles in 1960,54 roubles in 1970 , and 59 roubles in $1974,{ }^{28}$ so that it constituted $5^{6}, 44$, and $4^{2}$ per cent of the average wage, respectively. In 1980 , at a rough guess, it might have been about $66-73$ roubles. ${ }^{29}$

It can be assumed, too, that retired female workers average lower old-age pensions than retired male workers, because they average lower pre-retirement wages, are less often entitled to the privileged rate, and tend to have a shorter employment record. Since in the case of wages the male-female differential appears to be $30-35$ per cent, ${ }^{30}$ in that of old-age pensions it should be similar, if not greater. But $\mathrm{Yu}$. B. Ryurikov seems to be saying that the average old-age pension of retired female workers is lower than that of retired male workers by approximately one-fourth. ${ }^{31}$

Compared with retired workers, retired collective farmers are considerably worse off. As Table 2 discloses, their minimum old-age pension award lags behind that for workers, and the same applies to their average earnings. ${ }^{32}$ In addition, due to their rural connection as defined 
above, their old-age pension awards are more frequently reduced by I 5 per cent. By Alastair McAuley's estimate, the average monthly old-age pension of retired collective farmers amounted to 24 roubles in 1970 and to 33 roubles in $1974,{ }^{33}$ and might have risen to some 43 roubles in $1980 .{ }^{34}$

\section{Social Adequacy of Pensions}

For the period of i $966-70$, Soviet scholars calculated in the mid-sixties, the normative minimum budget for a notional urban family of four (consisting of a married couple, a boy of thirteen or fourteen, and a girl of seven or eight) was 205.60 roubles per month, or $5 \mathrm{I} .40$ roubles per family member. Food accounted for 55.9 per cent of the budget, and drink and tobacco for 2.7 per cent. ${ }^{35}$

The budget, which represented the poverty line for a family of the stipulated size and composition, suggested that the poverty line for a single urban worker was equivalent to a monthly income of 5 I .40 $\times$ I. I 5 , i.e. 59.1 r roubles. ${ }^{36}$ It could be assumed, then, that the poverty line for a single retired worker was equivalent to a monthly income of 59. I I $\times 0.8$, i.e. 47.29 roubles. ${ }^{37}$ Consequently, in 1970 the minimum old-age pension award of 30 roubles was considerably below the poverty line, and the average old-age pension of 54 roubles was less than 15 per cent above it.

For the period of $197 \mathrm{I}-5$, Soviet scholars adjusted the normative minimum budget for the same notional family of four to 265.80 roubles per month, or 66.45 roubles per family member ${ }^{38}$ That would imply that the poverty line for a single urban worker rose to $66.45 \times$ I. I 5 , i.e. 76.42 roubles per month, and that for a single retired worker to $76.4^{2} \times 0.8$, i.e. 61 . 14 roubles per month. Accordingly, in 1974 both the minimum old-age pension of around 45 roubles and the average old-age pension of 59 roubles were below the poverty line.

No adjustment of the normative minimum budget seems to have been published by Soviet scholars for the period of $197^{6-80}$. If, for lack of it, the poverty line for a single retired worker of 61.14 roubles per month were applied to this period as well, then in 1980 the minimum old-age pension award of 45 roubles continued to be substantially below the poverty line, and the average old-age pension of 66-73 roubles was about 8-19 per cent above it.

Although very rough, the estimates offered do suggest that old-age pensions of Soviet retired workers are modest and in many a case socially inadequate. A support for this assumption comes from a 
resolution adopted by the Central Committee of the CPSU and the Council of Ministers of the USSR in early $198 \mathrm{I}$. It promised that in the period of $1981-5$ long-standing pensions would be increased. The increase is to affect those recipients of pensions who used to be workers and were awarded a pension more than ten years ago. Implementation of the measure, which is to benefit in the first place pensioners receiving a pension of less than 60 roubles per month, is to go on in the next five-year period..$^{39}$

Significantly, the promised increase did not extend to collective farmers. On the other hand, the resolution admitted that the average old-age pension awarded earlier was smaller than that awarded later, so that recipients of long-standing old-age pensions were at a disadvantage. It implied, too, that the social adequacy of the average old-age pension awarded earlier was below that of the average old-age pension awarded later. ${ }^{40}$

It goes without saying, though, that-despite the absence of occupational old-age pensions - the standard of living of Soviet retired workers is not determined exclusively by the magnitude of their state old-age pension. It also depends on the dwelling and durable consumer goods they possess, their savings, their spouses' income, the financial support and other help they get from or give to their children and siblings, their receipts from and spending in the second economy, inflation (open, hidden and repressed), the health and social services provided by the state, etc. Besides, it depends on their post-retirement earnings from officially recognised employment, and these lead to the question of how and why they participate in social production.

\section{Mobilisation of Pensioners}

The Soviet Union is ageing, partly due to declining fertility and partly due to increasing life expectancy. If in 1939 persons of retirement age amounted to 8.9 per cent of the total population, they rose to 15.0 per cent in 1970 and are expected to reach 19.1 per cent in 2000.41

At the same time, the country is experiencing a shortage of labour, dating from the late sixties. Because of this shortage - which, however, does not mean non-existence of unemployment, both unregistered and hidden - the régime tries hard to encourage gainful employment beyond the relatively low legal retirement age, i.e. to induce able-bodied individuals either to carry on working after their retirement or to postpone their retirement.

Soviet scholars assert that in the first quinquennium after the 
TABLE 4. Retired workers

\begin{tabular}{cccc}
\hline & \multicolumn{3}{c}{ Retired white-collar and blue-collar workers } \\
\cline { 2 - 4 } Year & $\begin{array}{c}\text { All } \\
\text { (thousands) } \\
\text { (B) }\end{array}$ & $\begin{array}{c}\text { Of whom working } \\
\text { (thousands) } \\
\text { (A) }\end{array}$ & $\begin{array}{c}\text { (C) as a percentage } \\
\text { of (B) } \\
(\text { D) }\end{array}$ \\
\hline 1956 & 1,877 & 1,107 & (D) \\
1959 & 4,007 & 605 & 59.0 \\
1963 & 6,729 & 631 & 15.1 \\
1964 & 7,436 & 748 & 9.4 \\
1970 & 13,185 & 2,500 & 10.1 \\
1975 & $18,24^{2}$ & 4,424 & 19.0 \\
\hline
\end{tabular}

Sources: M. S. Lantsev, The Economic Aspects of Social Securty in the USSR, Progress Publishers, Moscow, 1979, pp. 84, 9o and 94-95; S. Smirnov, The employment of old-age pensioners in the USSR, International Labour Review, 116, I (1977), 92, table 2, and p. 94, table 4; Vestnik statistiki, no. 8 (1974), p. 95 .

attainment of retirement age approximately 80 per cent of old-age pensioners are capable of working (about one-third full time, about two-thirds part time or at home), and in the second approximately $3^{\circ}$ per cent. ${ }^{42}$ They also emphasise that in many cases a job actually promotes the old-age pensioner's health and wards off premature ageing.

Nevertheless, only a minority of retired workers participate in social production. While in $195^{6}$ close to three-fifths did, in 1963 the proportion was less than one-tenth. Subsequently, though, their proportion was increasing, to reach 24.3 per cent in I 975 (see Table 4 ) and 28 per cent (which amounted to over 6 million persons) in $1980 .{ }^{43}$

The figures quoted conceal that the majority of those retired workers who participate in social production (some 70 per cent in 1970) are men aged $60-64$ and women $55^{-59 ; 44}$ that most of those retired workers who participate in social production did not interrupt gainful employment after the award of their old-age pension; ${ }^{\mathbf{4 5}}$ that practically all retired workers participating in social production (99 per cent in the late seventies) work full time; ${ }^{46}$ and that retired female workers participate in social production less often than retired male workers. ${ }^{47}$

Further, the figures quoted do not show the share of retired workers in the labour force of the individual economic branches. But sample surveys conducted in the first half of the seventies found that persons of retirement age constituted 2-3 per cent of the labour force in industry, under 2 per cent in construction, $4^{-5}$ per cent in trade, 6-7 per cent in the health service, and $8-9$ per cent in municipal housing and consumer services. ${ }^{48}$ 
Lastly, the figures quoted do not comprise all persons of retirement age who participate in social production. In 1959 they amounted to 5.9 million, ${ }^{49}$ of whom 0.6 million were retired workers and the rest either collective farmers (who by then were not entitled to a state old-age pension) or those workers who had postponed their retirement (e.g. because they had not the employment record required). In I 970 their number fell (due to the introduction of a compulsory state old-age pension scheme for collective farmers in the mid-sixties) to 4.5 million, ${ }^{50}$ of whom 2.5 million were retired workers.

Thus, while in the late fifties collective farmers predominated among persons of retirement age participating in social production, in the seventies retired workers did. ${ }^{51}$ And in this connection it should be asked how the latter's participation in social production has been manipulated by the régime.

Between $193^{8}$ and 1956 , retired workers participating in social production could draw their old-age pension in full regardless of their earnings. However, the 1956 Act changed the situation. Under it, while participating in social production, retired workers had their monthly old-age pension reduced to a mere 15 roubles if earning less than 100 roubles per month, and suspended if earning over roo roubles per month. ${ }^{52}$ On top of that, whereas their old-age pension was exempt from taxation, their earnings were not.

As Table 4 discloses, this had (and was intended to have) an adverse impact on retired workers' participation in social production. Consequently, when demand for retired workers' participation in social production increased, the rules concerning the concurrence of old-age pensions and earnings were relaxed. Originally, as from i April 1964, most retired workers participating in social production became entitled to 50 per cent of their monthly old-age pension ( 75 per cent in the Urals, Siberia and the Far East) and some to Ioo per cent, with a pensioncum-earnings ceiling of 200 roubles per month. Later, as from I January I970, most retired workers participating in social production became entitled to 100 per cent of their monthly old-age pension, with a pension-cum-earnings ceiling of 300 roubles per month.

Due to these changes, between 1968 and 1973 the proportion of working old-age pensioners receiving their old-age pension in full rose from 34.3 per cent to 91.4 per cent. Concomitantly, the proportion of those receiving 50 to 75 per cent declined from 30.8 per cent to 5.7 per cent, and the proportion of those receiving 15 roubles per month or no old-age pension at all fell from 34.9 per cent to 2.9 per cent. ${ }^{53}$

While the régime has been encouraging retired workers' participation in social production since 1964 , it was slow to take another step, long 
advocated by some Soviet scholars, namely, to induce workers to postpone their retirement in the sense that they would remain economically active beyond their retirement age without claiming an old-age pension and would be rewarded by a higher old-age pension when they later retired. The step was taken only in 1979 and came into force on I January $1980 .^{54}$

More specifically, retired workers were given the option of refraining from drawing their old-age pension while gainfully employed and, instead, being credited with an old-age pension supplement of ro roubles for each year of service after their reaching retirement age. If they choose to do so, they will be credited with the supplement after they have ceased working, but the total supplement must not exceed 40 roubles and the total old-age pension (including the supplement) I 50 roubles per month.

Since the Soviet Union is experiencing a shortage of labour, the régime's attempts to mobilise persons of retirement age for participation in social production are easy to understand. On the other hand, why has it been reluctant to alleviate this shortage either by raising the relatively low legal retirement age or by substituting invalidity pensions for old-age ones, although suggestions to that effect have not been absent?

Obviously, raising the retirement age or returning to the pre-1928 practice of viewing old age as a kind of invalidity would be politically embarrassing as well as highly unpopular. In contrast, the two policies outlined above avoid these consequences and, on top of that, enable the régime both to regulate the labour supply from among persons of retirement age and to steer them into particular economic branches (such as production, trade and services), occupations (e.g. manual as opposed to engineering-technical), and regions. Thus, if the demand for labour decreased, the rules concerning the concurrence of old-age pensions and earnings and those concerning deferred old-age pensions could be tightened quickly and without much fuss.

\section{Pensioners' motives}

Concomitantly with the régime's attempts to mobilise persons of retirement age for participation in social production, Soviet scholars have been inquiring into retired workers' motives to work. During the seventies, before the introduction of deferred old-age pensions, social surveys tried to ascertain why some retired workers did and others did not participate in social production, and under what circumstances the latter would be willing to take up a job. 
Most retired workers participating in social production (approximately $54-58$ per cent) do so for economic reasons. The possible explanations are that they find their old-age pension award insufficient to live on, or that they want to help their adult children materially, ${ }^{55}$ or that they wish to save up money for rainy days.

The remaining retired workers participating in social production do so for non-economic reasons. These include, inter alia, the need for daily work, attachment to one's speciality, and the desire to be in a collective. Their incidence depends on income and sex: it increases the higher the family per capita income and vice versa, ${ }^{56}$ and is greater among men than among women. ${ }^{57}$

Expressed differently, since the event of retirement leads to major changes in role and status, by continued participation in social production retired workers endeavour to avoid, at least for the time being, some of its consequence, such as a diminished income, loss of regular and goal-oriented activity and eventually of power or influence as well, rusting of acquired skills, strain within the family, social isolation, feelings of loneliness, boredom, etc.

It has been found, too, that most retired workers participating in social production stay at their pre-retirement place of work and, compared with those who after retirement have changed their place of work, are more likely to carry on working in the same occupation as before. ${ }^{58}$ Besides, it has been found that the productivity of retired workers aged $60-64$ is merely one-tenth below the average for all age groups..$^{59}$

Health is by far the main reason given by retired workers for not taking part in social production although, obviously, it can often be cited as an excuse concealing the real reason. The second main reason given is family responsibilities, such as housework, care for the sick, and upbringing of grandchildren. This reason explains why, as mentioned above, the incidence of non-economic reasons for participation in social production is greater among retired male workers than among retired female workers.

Undoubtedly, also, the other reasons given (the absence of opportunities for part-time work, less heavy physical work, work carried on at home, and work close to home) can be cited as an excuse concealing the real reason. And one possible real reason for not taking part in social production is active involvement in the second economy.

No evidence on how retired workers not taking part in social production are actively involved in the second economy seems to have been collected. An exception is the cultivation of private plots. Among the miners surveyed in the Central Urals, for instance, those with a 
private plot intended to retire and fully withdraw from participation in social production at the age of 50 more often than those without it, and those with a family per capita income of under 50 roubles per month but a private plot more often than those with a higher family per capita income. ${ }^{60}$ Thus, the availability of a private plot tends to weaken interest in post-retirement participation in social production.

When interviewed, some of the retired workers not taking part in social production expressed willingness to resume gainful employment under certain conditions. As follows from the above-mentioned, these include opportunities for part-time work, less heavy physical work, work carried on at home, work close to home, and so on. ${ }^{61}$ There is no guarantee, though, that this verbally stated willingness would actually lead to resumption of gainful employment, if the conditions named by the respondents materialised: it has been found that if upon retirement workers withdraw from participation in social production, the probability of their re-entering the labour force decreases.

Of the conditions named by the respondents, the most important appears to be part-time work. It has been desired by women of working age as well as retired workers, advocated by scholars, ${ }^{62}$ and promised by the régime for well over a decade. Nevertheless, its incidence has remained limited: in 1978 , approximately 500,000 persons worked part-time in the country as a whole, constituting less than 0.5 per cent of all white-collar and blue-collar workers. ${ }^{63}$

Both the results of several surveys and letters in the press attest to the fact that a number of Soviet managers are reluctant to hire on a part-time basis, to retain workers upon retirement, and to hire retired workers. The managers in question argue that part-time work would lead to the under-utilisation of capital equipment, that it would play havoc with enterprise work schedules, that workers of retirement age are more prone to absenteeism due to illness than workers of working age, that the former have a lower productivity than the latter, and the like. Their critics point out, though, that at least some of the reasons given are not supported by empirical findings.

However, even if the critics were right, this reluctance by Soviet managers should be seen in a broader context. On the one hand, upon retirement many workers are willing to carry on working only in the same occupation as before and/or if special working conditions are created for them, possess outdated technical skills. ${ }^{64}$ On the other hand, the nature of directive economic management makes it difficult for managers to create special working conditions for retired workers and to hire all available ones, and at the same time to meet the various plan targets. Thus, at the enterprise level the provision of employment opportunities for retired workers must be balanced against the tasks set 
and constraints imposed from above, with the outcome that retired workers' wishes need not be satisfied and the blame put on managers' shoulders.

Just as retired workers, also retired collective farmers seem to participate in social production predominantly for economic reasons, to withdraw from participation in social production for reasons of health, family responsibilities and private plot work, and to be inclined to resume gainful employment if, inter alia, there existed opportunities for part-time work. In any case, these are the findings of a survey conducted among nearly 3,00o collective farmers in the first quinquennium after their reaching retirement age, of whom $4^{2}$ per cent did not participate in social production. ${ }^{65}$

Upon retirement, female collective farmers appear to withdraw from participation in social production more often than male collective farmers. In the survey quoted in the preceding paragraph, for instance, women constituted 87.3 per cent of those who did not take part in social production. In 1978 , according to another source, female collective farmers of retirement age contributed almost 25 per cent of private plot work, but less than 3 per cent of collective farm work. ${ }^{66}$

In sum, upon retirement both workers and collective farmers may either continue or discontinue economic activity. The former can assume the form of participation in social production or that of participation in the second economy, including the cultivation of private plots. The latter can result in concentration on family responsibilities (especially in the case of women), pursuit of a hobby, a life of leisure, etc.

When retirees are legally allowed to draw a wage in addition to the full amount of their old-age pension, one clear and immediate advantage of post-retirement participation in social production is a temporarily increased income, which is of particular significance for those who are motivated by economic reasons to carry on working after retirement. Most probably, this advantage will tend to reduce interest in the institution of deferred old-age pensions. ${ }^{67}$

On the other hand, the concurrence of old-age pensions and wages has at least two disadvantages. It can rouse envy among persons of working age and have a demoralising effect on them. And it puts a strain on the régime's resources: while in 1972 working pensioners received about 2 milliard roubles in pensions, ${ }^{68}$ in 1980 (at a rough guess) retired workers participating in social production received in old-age pensions over 5 milliard roubles. Thus, a more widespread use of the institution of deferred old-age pensions would undoubtedly be to the régime's advantage.

At the same time, the retirees who want to be economically active 
frequently have a choice between participation in social production and participation in the second economy. It may be assumed that, provided the choice exists and the striving for post-retirement economic activity stems from economic reasons, the economic attractiveness of the former will be compared with that of the latter and the latter will prevail over the former if it is expected to yield a higher income.

\section{Conclusion}

Over the years, the proportion of persons of retirement age receiving a state old-age pension has been increasing in the Soviet Union. Simultaneously, since 1956 the average nominal old-age pension of retired workers and since 1965 that of retired collective farmers have been rising, although retired collective farmers have continued to average lower old-age pensions than retired workers.

Yet, despite rising average nominal old-age pensions, the relative economic position of the average retired worker has deteriorated and that of the average retired collective farmer has improved only slightly. As to the former, while in 1960 retired workers' average monthly old-age pension in payment amounted to $5^{6}$ per cent of workers' average monthly wage, in 1980 it amounted to a mere $4 \mathrm{I}$ per cent. As to the latter, while in i 970 retired collective farmers' average monthly old-age pension payment amounted to 32 per cent of collective farmers' average monthly earnings, in both 1974 and 1980 it amounted to $3^{6}$ per cent.

By the standards used in the present examination, old-age pensions of retired workers - and even more so those of retired collective farmers - are modest and in many a case socially inadequate. Obviously, they are not the sole factor determining the retirees' standard of living. But it should be remembered that, compared with the developed industrial societies of the West, the standard of living of the Soviet population is low. According to one estimate, in 1976 per capita consumption was at roughly 37 per cent of the level in the United States, and this did not take into consideration qualitative deficiencies in the supply of Soviet consumer goods. ${ }^{69}$

Although modest, old-age pensions in payment do impose a burden on both the régime and the population of working age. In 1960 they drained approximately 1.7 per cent of national income, by 1970 it had risen to approximately 4.0 per cent and by I 980 approximately 5.4 per cent. ${ }^{70}$ The burden can be expected to become heavier in the 1980 and the rg9os, due to the ageing of the country and a slowdown in Soviet economic growth. 
While the régime incessantly advertises its care for the aged, it is reluctant to assume total and exclusive responsibility for them. The official culture regards income maintenance in old age as the most important means of caring for the aged. However, as soon as gainfully employed persons reach retirement age and are awarded an old-age pension, they tend to be forgotten: since old-age pension awards are not automatically adjusted to the rising wage level, their original magnitude is likely to remain unchanged throughout their recipients' retirement.

Besides income maintenance in old age, ${ }^{71}$ the régime provides medical care, some social services, and limited institutional care for the aged. ${ }^{72}$ But at the same time it expects that, in addition, the aged will be looked after by their families ${ }^{73}$ and given help by their former employers, the trade unions, and other mass organisations.

Nevertheless, in one respect the régime does not forget the aged, namely, as a potential source of manpower. Although unemployment is far from absent, simultaneously there is a shortage of labour. Also, the official culture attaches a high value to conscientious and socially useful work and extols the man of work. Consequently, the current interest of the régime in the aged is strongly (and perhaps primarily) instrumental in character.

As the available evidence shows, the régime has succeeded in mobilising the aged (especially those in the first quinquennium after their reaching retirement age) for participation in social production: since the early I 970 , upon retirement, approximately six out of each ten workers and a similar proportion of collective farmers seem to have chosen to continue taking part in it. However, a further substantial increase in the labour force participation rate of the aged is hardly probable.

On the other hand, fragmentary data suggest that many retired workers participating in social production hold low-skill and low-paying jobs which do not attract persons of working age. According to one source, for instance, in the late r 970 os one-third of working pensioners were employed in enterprise security. ${ }^{74}$

If the aged play an active role in the official economy, they also play an active role in the second economy and in the households of their adult children. In the former role they help to supply those desired consumer goods and services which the official economy does not supply. In the latter role, which includes upbringing of grandchildren, they enable their adult children (particularly women) to participate in social production.

At this juncture it should be asked whether the lot of the aged, in so far as it depends on the régime's allocations, can be expected to 
improve considerably in the foreseeable future. The answer appears to be in the negative. Although the average nominal old-age pension in payment will go on rising, ${ }^{75}$ the gap between it and the average wage is unlikely to diminish noticeably. It is unlikely, too, that the medical care, social services and institutional care provided by the régime will be able to meet the aged's demand and need more adequately than hitherto.

The assumption just made is based on two main reasons, already mentioned above. First of all, the Soviet Union is ageing. ${ }^{76}$ It was estimated, for instance, that in the $198 \mathrm{I}-85$ period about 9 million persons would become entitled to an old-age pension and the number of retirees would go up from 34 million to 40 million. ${ }^{77}$ And in 2000, by Western projections, persons of retirement age are likely to reach 58.9 million, constituting I9.I per cent of the total population.

On top of that, in the 1980 s and the r 990 os the burden imposed by the increasing number and proportion of old-age pensioners will be aggravated by a slowdown in Soviet economic growth. The slowdown will make it more difficult for the régime to balance the shares of defence, investment and consumption in national income. And since the régime is unlikely to give priority to consumption at the expense of defence and investment, the population will hardly escape unscarred. That is to say, its relatively low standard of living will at best improve at a slower pace than in the second half of the r 970 .

At the same time, when planning the distribution of the share of national income earmarked for consumption, the régime will have to attach greater weight to the economically active population than to the aged. If it neglected the former, especially blue-collar workers, popular unrest and socio-political instability might ensue, because its legitimacv is based less on normative principles than on utilitarianism (material gratification). If it substantially bettered the economic lot of the latter, many able-bodied retirees might lose interest in taking part in social production.

\section{NOTES AND REFERENCES}

I On the development of Soviet social security see e.g. Margaret Dewar, Labour Policy in the USSR 1917-1928, Royal Institute of International Affairs, London and New York, 1956; Bernice Q. Madison, Social Welfare in the Soviet Union, Stanford University Press, Stanford, California, 1968, chapters 4 and 11 ; Gaston V. Rimlinger, Welfare Policy and Industrialization in Europe, America, and Russia, Wiley, New York, 197 I, chapter 7.

2 This figure refers to the European part of the Soviet Union in 1926-7. The life expectancy at birth of men as a group was 42 years and that of women as a group 47 years. (Narodnoe khozyaistvo SSSR, 1977, p. 90.) 
3 Vestnik statistiki, 1974 , no. 8, p. 95.

4 M.S. Lantsev, The Economic Aspects of Social Security in the USSR, Progress Publishers, Moscow, 1979, p. 82, table 19.

5 For a Russian text of the law see Gosudarstvennoe sotsial'noe strakhovanie: Sbornik ofitsial'nykh materialov, Izdatel'stvo VCSPS Profizdat, I963, pp. 169-185.

6 According to Soviet sources, prior to the 1956 Act pensions had been regulated by 960 normative acts.

7 J. L. Porket, Old age pension schemes in the Soviet Union and Eastern Europe, Social Policy and Administration, 13, I (1979), 22-3.

8 In 1959, collective farmers and their dependants constituted 31.4 per cent of the Soviet population. (Narodnoe khozyaistvo SSSR, 1 979, p. 8.)

9 Calculated from Narodnoe khozyaistvo SSSR, 1964, p. 602, and ibid. 1965, p. 607.

ro Between 1956 and 1964 , collective farmers were entitled to a state pension in certain cases, e.g. if they became disabled in the course of military service; or if they were machinists, skilled workers, technicians or engineers who moved from employment in a state organisation to a collective farm; or if they became full-time state farm workers as a result of the conversion of a collective farm into a state farm.

I I The scheme was established by a law adopted on 15 July 1964. For an English text see Mervyn Matthews, Soviet Government: A Selection of Official Documents on Internal Policies, Jonathan Cape, London, 1974, pp. 370-375.

12 Narodnoe khozyaistvo SSSR, 1980, p. 4I I.

13 Originally, under the 1964 Act, the retirement age was set at 65 for male collective farmers and 60 for female collective farmers.

I 4 Previously, under the 1964 Act, the maximum old-age, invalidity and survivors' pensions for collective farmers were fixed at the level of the maximum old-age, invalidity and survivors' pensions stipulated in the 1956 Law on State Pensions for those white-collar and blue-collar workers who lived permanently in rural localities and were engaged in agriculture. In the case of old-age pensions it was 102 roubles instead of 120 roubles.

15 V. A. Acharkan, Aktual'nye problemy pensionnogo obespecheniya, in G. S. Sarkisyan (ed.), Dokhody trudyashchikhsya i sotsial'nye problemy urovnya zhizni naseleniya SSSR, Moskva, 1973, pp. 144-145.

16 The Model Charter of the Collective Farm, approved by the Third All-Union Congress of Collective Farmers, 25-27 November 1969, Article 40, in Sotsial'noe strakhovanie v SSSR: Sbornik ofitsial'nykh materialov, Profizdat, I97 1, p. 268.

17 Personal pensions (first introduced in July 1920) and long-service pensions (first introduced in the mid-twenties) are discussed by Robert J. Osborn, Soviet Social Policies: Welfare, Equality, and Community, The Dorsey Press, Homewood, Illinois, 1970, pp. 76-84, and Mervyn Matthews, Privilege in the Soviet Union: A Study of Elite Life-Styles under Communism, George Allen \& Unwin, London, 1978, pp. 37-38, $85-87$ and $103-104$. It goes without saying that the personal pensions which are awarded by the state and those which can be granted by collective farms are not identical.

I 8 Akademiya nauk SSSR, Sotsial'noe razvitie rabochego klassa SSSR, Izdatel'stvo 'Nauka', Moskva, 1977, p. I63.

19 By the end of 1980 , there were 34 million old-age pensioners in the Soviet Union. (Narodnoe khozyaistvo SSSR, I980, p. 4 I I.) However, persons of retirement age were estimated to amount to 40.9 million. Consequently, nearly 7 million persons of retirement age were not receiving an old-age pension, although at least some of them were receiving another kind of state pension and others were drawing a wage, having postponed their retirement. 
20 In more detail see Pavel Stiller, Die sowjetische Rentenversicherung 1917-1977, Bundesinstitut für ostwissenschaftliche und internationale Studien, Köln, I979, pp. 43-44.

2 I Both in the mid-sixties and the mid-seventies, probably no more than 12 per cent of retired workers were receiving old-age pensions calculated at the privileged rate.

22 Since 1976, coal and shale miners, underground workers at enterprises of the ministries of ferrous and non-ferrous metallurgy, and workers in mine-construction organisations have been entitled to a maximum old-age pension award of 140 roubles a month after $15^{-20}$ years of work, or 160 roubles a month after more than 20 years of work.

23 V. P. Slobozhanin, Pensiya - po trudovomu vkladu, Sovetskoe gosudarstvo i pravo, I 981 , no. 9, p. 47 . The first survey was conducted in the RSFSR and covered 10o, ooo old-age pensioners. The second survey was conducted in three large industrial enterprises situated in the town of Minsk and covered all workers who had retired between $197 \mathrm{I}$ and 1975 .

24 Pavel Stiller, Probleme bei der Anwendung der sowjetischen Rentengesetze, Osteuropa-Wirtschaft, 23, no. 4, (1978), 272-273; V. P. Slobozhanin, op. cit. pp. $47-48$; V. G. Blufard, $K$ voprosu ob effektivnosti truda pensionerov, Sotsiologicheskie issledovaniya, no. 2 ( 1982 ), p. 168.

25 On average, men draw a pension for over 16 years and women for over 24 years. (M. Lantsev, Razvitie sotsial'nogo obespecheniya i ego vozdeistvie na trudovuyu aktivnost' zanyatykh v obshchestvennom proizvodstve, Sotsialisticheskii trud, I 98 I, no. 3 , P. 51 .)

26 V. P. Slobozhanin, op. cit. pp. 49-52. The author is of the opinion that the change would enable consideration to be taken of the workers' long-term performance, as well as reduce pre-retirement labour turnover induced by the workers' striving to bloat their reference wage.

27 Rimlinger, Welfare Policy, p. 280, and Stiller, Die sowjetische Rentenversicherung, p. 62, table 16.

28 Alistair McAuley, Economic Welfare in the Soviet Union. Poverty, Living Standards, and Inequality, The University of Wisconsin Press, Madison, Wisconsin, 1979, p. 275.

29 The estimate proceeds from the average old-age pension in 1974, takes into consideration year-by-year increases in the number of retired workers, and assumes that in each year between 1975 and 1980 the average old-age pension award amounted to 55 per cent of the average wage. After the estimate was made, the figure of 70 roubles for 1980 (constituting $4^{1}$ per cent of the average wage in that year) was reported by Stephen Sternheimer, The graying of the Soviet Union, Problems of Communism, 31, 5 (1982), 86.

$30 \mathrm{~J}$. L. Porket, Sex-related differences in income under Soviet-type socialism, Osteuropa-Wirtschaft, 27, 3 (1982), 2 13-229.

31 Yu. B. Ryurikov, Deti i obshchestvo, Voprosy fllosofii, no. 4 (I977), pp. I I 8-I I 9.

32 In 1978 , for instance, while the average monthly wage in the national economy was 159.9 roubles, collective farmers earned on average merely 109.9 roubles. (G. S. Vechkanov, Migratsiya trudovykh resursov o SSSR, Izdatel'stvo Leningradskogo Universiteta, Leningrad, I981, p. 127, (table 5.) It should be recalled that until I 966 collective farmers received no wages, but a share of the net income of the collective farm. As from July 1966 , guaranteed monthly payments in cash were introduced in collective farms and were to be based on the wage scales in force in state farms.

33 McAuley, op. cit. p. 275.

34 After the estimate was made, the figure of 42 roubles was reported by Sternheimer, op. cit. p. 86. 
35 Mervyn Matthews, Class and Society in Soviet Russia, Allen Lane The Penguin Press, London, 1972, pp. 8i-84.

36 A higher coefficient could be possible, though, as follows from McAuley, op. cit. pp. I 8, I 17,207 and 357.

37 This coefficient too is rather arbitrary. Soviet scholars recognise that the poverty line for a single retired worker lies below that for a single urban worker, but do not attempt to quantify the difference.

38 Aaron Vinokur and Gur Ofer, Family income levels for Soviet industrial workers, I965-1975, in Arcadius Kahan and Blair A. Ruble (eds), Industrial Labor in the U.S.S.R., Pergamon Press, New York, 1979, p. 19 I. In addition see A. Ya. Kvasha, Demograficheskaya politika o SSSR, 'Finansy i sta tistika', Moskva, I98 I, pp. I62-I63.

39 Pravda, 3 I March ig8r.

40 As shown elsewhere, a gap between the average old-age pension awarded earlier and the average old-age pension awarded later arises in Soviet-controlled Eastern Europe as well, with similar consequences for their social adequacy. (J. L. Porket, Inequalities in Eastern Europe: The case of Old-Age Pensioners, Oxford, St. Anthony's College, Papers in East European Economics, no. 64, I980, pp. 35-36 and 57-58.)

4 I Murray Feshbach, Employment Trends and Policies in the U.S.S.R., CESES, l'Est, Quaderni, no. Io (1978), p. 71 , table 2.

42 A. Novitskii and M. Babkina, Ratsional'nee ispol'zovat' trud pensionerov, Sotsialisticheskii trud, 20, 8 (1975), I19, and M. Ya. Sonin, Razvitie narodonaseleniya: Ekonomicheskii aspekt, Statistika, Moskva, 1980, p. 331.

43 Lantsev, Razvitie sotsial'nogo obespecheniya..., p. $5^{2}$.

44 V. G. Kostakov (ed.), Trudovye resursy: Sotsial'no-ekonomicheskii analiz, Izdatel'stvo 'Ekonomika', Moskva, 1976, p. 7 I n.I.

45 The remainder re-entered the labour force after a break lasting several months or several years. (Novitskii and Babkina, op. cit. p. I 24.)

46 Sonin, op. cit. pp. $33^{1-332 .}$

47 Acharkan, op. cil. p. 148, and Kostakov (ed.), op. cit. p. 71.

48 Novitskii and Babkina, op. cit. p. I 18.

49 A. Kotlyar, Sotsialisticheskii stroi i prodolzhitel'nost' perioda trudovoi deyatel'nosti, Nauchnye doklady vysshei shkoly: Ekonomicheskie nauki, 10, 6 (ig67), 40.

$5^{\circ}$ Of these, 1.7 million were men and 2.8 million women. (N. V. Fedorova, Sotsial'no-ekonomicheskii sostav naseleniya SSSR, In G. M. Maksimov (ed.), Vsesoyuznaya perepis' naseleniya 1970 goda, 'Statistika', Moskva, (1976, p. 219.)

5I See also V.A. Acharkan, Tekushchie i perspektivnye problemy sotsial'nogo obespecheniya, Sovetskoe gosudarstvo i pravo, no. 4 (1977), p. 25.

$5^{2}$ Retired workers entitled to the privileged rate were an exception: they received 50 per cent of their old-age pension regardless of their earnings. On the other hand, any retired worker could have his old-age pension recalculated if after retirement he worked no less than two years and during that period his earnings exceeded those from which his old-age pension award was calculated.

53 Lantsev, Economic Aspects of Social Security, p. 93, table 24.

54 By that time a similar measure had long been in force in Czechoslovakia, Hungary and Bulgaria.

55 In a survey conducted in $1977-8,64$ per cent of working and 26 per cent of nonworking old-age pensioners supported their adult children materially. (V. D. Shapiro, Vzaimootnosheniya starshego i srednego pokolenii sem'i, Sotsiologicheskie issledovaniya, no. 1 , 1981 , p. 131 , table 2.)

56 S. Smirnov, The employment of old-age pensioners in the USSR, International Labour Review, 116, I (1977), 89.

57 A. Novitskii and M. Babkina, Nepolnoe rabochee vremya i zanyatost' naseleniya, 
Voprosy ekonimiki, no. 7 (1973), pp. 133-140, and N. V, Panina, Podgotovka k vykhodu na pensiyu kak uslovie adaptatsii k statusu pensionera, Sotsiologicheskie issledovaniya, no. 3, 1979, pp. 101-107.

$5^{8}$ Novitskii and Babkina, Ratsional'nee ispol'zovat' trud pensionerov, pp. 1 23-1 24:

59 S. Smirnov, op. cit. p. 88, table I, and I. V. Kalinyuk, Vozrastnaya struktura naseleniya SSSR, 'Statistika', Moskva, I975, p. I 8, Table I.

60 E. V. Polzik and V.S. Kazantsev, Metody opredeleniya vliyaniya sotsial'nykh faktorov na prodolzhitel'nost' trudovoi deyatel'nosti pozhilykh shakhterov, Sotsiologicheskie issledovaniya, no. 2 (1979), pp. 93-96.

6I According to V. Korchagin (Rol' zdravookhraneniya v vosproizvodstve trudovykh resursov, Voprosy ekonomiki, no. 12,1981, p. 72), for instance, the surveys conducted among persons of retirement age have shown that post-retirement participation in social production could be induced by a shorter working day (about 30 per cent of the respondents), pay for the time actually worked ( 24 per cent), better organisation and régime of work ( 15 per cent), work carried on at home (10 per cent), and so on.

62 One of the arguments used by them has been the finding that the hourly productivity of part-time workers (whether of working or retirement age) is higher than that of full-time workers.

63 N. Rogovskii, Effektivnost' truda v odinnadtsatoi pyatiletke, Voprosy ekonomiki, no. I (1982), p. 6.

64 In the surveys conducted in 1973 among more than 5,000 working persons of retirement age, merely 12 per cent of skilled workers wanted to be retrained. And among those interviewed non-working pensioners who desired to resume gainful employment, merely 30 per cent were disposed to change their occupation. (Novitskii and Babkina, Ratsional'nee ispol'zovat' trud pensionerov, p. 1 18.)

65 V. Sheiko, V. Berko and T. Dovgalyuk, Pensioner v kolkhoze, Sotsialisticheskii trud, no. 7 (1982), pp. $78-79$.

66 G. Shmelev, Obshchestvennoe proizvodstvo i lichnoe podsobnoe khozyaistvo, Voprosy ekonomiki, no. 5 (198I), p. 68.

67 Another factor which might reduce interest in the institution of deferred old-age pensions is the level of the old-age pension supplement: many might regard a monthly old-age pension supplement of to roubles for each year of service after their reaching retirement age as an insufficient compensation for not claiming their old-age pension while working. Theoretically, the institution could appeal to two categories of persons of retirement age: to those who would have a low old-age pension if they retired upon reaching retirement age and at the same time have no spouse, children and relatives, and to those who after reaching retirement age would be able to continue to draw a wage approaching the pension-cum-earnings ceiling of 300 roubles per month.

68 Archarkan, Aktual'nye problemy pensionnogo obespecheniya, p. 150.

69 Abram Bergson, Soviet economic slowdown and the 1981-85 plan, Problems of Communism, 30, 3 ( $198 \mathrm{r}$ ), 33. At the official rates of exchange, according to another estimate, the monthly take-home pay of Soviet industrial (manufacturing) workers in December 1981 was less than one-quarter of the U.S. level and less than one-third of the British one. The purchasing power of these workers, measured in terms of a weekly family food basket, was about one-third of the U.S. level and about one-half of the British one. Keith Bush, Retail Prices in Moscow and Four Western Cities in March, 1982, Radio Liberty Research Supplement, 4 June 1982, pp. 7 and 32 .)

70 Own estimate. Soviet statistical yearbooks enable one to calculate exclusively the share of national income spent on all pensions: it was 4.9 per cent in $1960,5.6$ per cent in 1970 , and 7.3 per cent in 1980 . 
7r Currently, as already mentioned above in the text, while most aged receive an old-age pension and a minority another kind of state pension, some still appear to receive no kind of state pension at all.

72 Neither the health and social services nor the institutional care provided by the state seem to meet the needs of the aged. By the beginning of the 1980 , for instance, homes for the elderly and disabled accommodated only about 353 thousand persons. (Lantsev, Rasvitie sotsial'nogo ovespecheniya, p. 52.)

73 However, there is a considerable number of the solitary aged in the Soviet Union. The same applies to Soviet-controlled Eastern Europe.

74 Sonin, op. cit. p. 284 .

75 This, of course, does not take into consideration open, hidden and repressed inflation. The official retail price index, which reflects open inflation, was Ioo in 1970, 99.7 in 1975, and 104 in 1981 . (Narodnoe khozyaistvo SSSR, 1922-1982, p. 479 .)

76 The ageing of the Soviet population is regionally differentiated, though. In more detail see Murray Feshbach, Between the lines of the 1979 Soviet census, Problems of Communism, 31, I (1982), 27-37.

77 Lantsev, Razvitie sotsial'nogo obespecheniya, p. $5^{2}$. 